\title{
Wisata Religi Berbasis Kearifan Lokal dan Pemberdayaan Ekonomi Masyarakat Adat Kampung Dukuh
}

\author{
Ai Juju Rohaeni ${ }^{1}$ dan Nia Emilda ${ }^{2}$ \\ Program Studi Kriya Seni, Fakultas Seni Rupa dan Desain \\ Institut Seni Budaya Indonesia (ISBI Bandung) \\ Jalan Buahbatu No. 212, Bandung \\ Tlp.085720383761,aijujurohaeni1961@gmail.com ${ }^{1}$
}

\begin{abstract}
Religious tourism is a journey or visit undertaken by travelers with the intent of enriching their religious insights. A type of religious tourism commonly done by Indonesian people is the ziyarat - a pilgrimage trip to holy places or graves. Ziyarat is done as a means of saluting the deceased who was knowledgeable, especially about religion; a role model; or a hero who dedicated his life to his country. Ziyarat can also include visiting sacred sites or places. Dukuh Customary Village is visited by many tourists who want to see its uniqueness and also to perform ziyarat to Syekh Abdul Jalil's tomb. Syekh Abdul Jalil was the founder of Dukuh Customary Village and the man who gave the village its name as well. He was also an Imam who spread the teachings of Islam in West Java. Besides improving one's understanding, especially about religion, religious tourism has positive impacts on the economic empowerment of the local community. This study employs a qualitative approach with a descriptive method. Its result comprehensively describes the activities of religious tourism and their impacts on the economic empowerment of the local community in Dukuh Customary Village located in the Cikelet District of Garut Regency.
\end{abstract}

Keywords: religious tourism, local genius, economic empowerment, local community of Dukuh Customary Village

\begin{abstract}
ABSTRAK
Wisata religi merupakan aktivitas perjalanan atau kunjungan yang dilakukan untuk menambah wawasan keagamaan. Salah satu wisata religi yang biasa dilakukan oleh masyarakat Indonesia adalah ziarah. Ziarah dilakukan sebagai penghormatan kepada yang dianggap mempunyai kelebihan ilmu, terutama ilmu agama, menjadi panutan, atau mengabdikan dirinya untuk bangsa dan negara selama hidupnya. Ziarah juga dilakukan ke situs atau tempat yang dianggap sakral. Kampung Adat Dukuh banyak dikunjungi wisatawan untuk melihat keunikan juga melaksanakan ziarah ke Makom Syekh Abdul Jalil, orang yang pertama menemukan dan memberi nama kampung Dukuh dan juga ulama yang ikut menyebarkan agama Islam di Jawa Barat. Wisata religi ini ternyata tidak hanya berdampak pada bertambahnya wawasan keagamaan dan keilmuan, tetapi juga memiliki dampak positif bagi pemberdayaan ekonomi masyarakat setempat. Penelitian ini menggunakan pendekatan kualitatif dengan metode deskriptif. Hasil penelitian menggambarkan secara komprehensif tentang aktifitas wisata religi serta dampaknya terhadap pemberdayaan ekonomi masyarakat Kampung Adat Dukuh Kecamatan Cikelet Kabupaten Garut.
\end{abstract}

Kata Kunci: Wisata Religi, Kearifan Lokal, Pemberdayaan Ekonomi, Masyarakat kampung Adat Dukuh 


\section{PENDAHULUAN}

Kabupaten Garut memiliki dua kampung adat yaitu Kampung Dukuh dan Kampung Pulo. Penelitian ini dilakukan di Kampung Dukuh yang berada di Desa Ciroyom Kecamatan Cikelet. Masyarakat Adat Dukuh mempunyai keunikan tersendiri dalam kehidupan sosial budayanya dari kampung adat lain yang ada di Jawa barat. Selain dikenal dengan kampung yang sangat mentaati aturan adat, kampung ini juga merupakan kampung yang sarat dengan aturan agama. Kekhasan lain dengan kekuatan kharisma dari pimpinan Kampung Adat Dukuh yang disebut Kuncen, seorang Kuncen sangat dihormati dan ditaati ajaran, ucapan/nasehat-nasehatnya serta perilaku hidupnya.

Keunikan lain yang ada di kampung adat Dukuh dalam organisasi kepengurusan diluar kepengurusan pemerintah Rukun Warga dan Rukun Tetangga, selain Kuncen adanya yang disebut Lawang, yang tidak ada di masyarakat adat lainnya. Fungsi Lawang tidak kalah pentingnya dan tidak sembarang orang, karena ada tahapan untuk menjadi Lawang.

Lawang di masyarakat adat Dukuh ada Lawang perempuan dan laki-laki yang bertugas dan bertanggung jawab untuk membantu dan mengganti tugas Kuncen pada kegiatan ritual apabila Kuncen berhalangan.

Kuncen dan keturunannya mempunyai kedudukan dan tempat terhormat, tidak hanya sewaktu hidupnya saja, tetapi dimuliakan sampai akhir hayatnya. Hal tersebut dapat dilihat pada tempat dan posisi makom Pimpinan adat yang sangat dihormati dan menjadi panutan., baik dengan berziarah pada

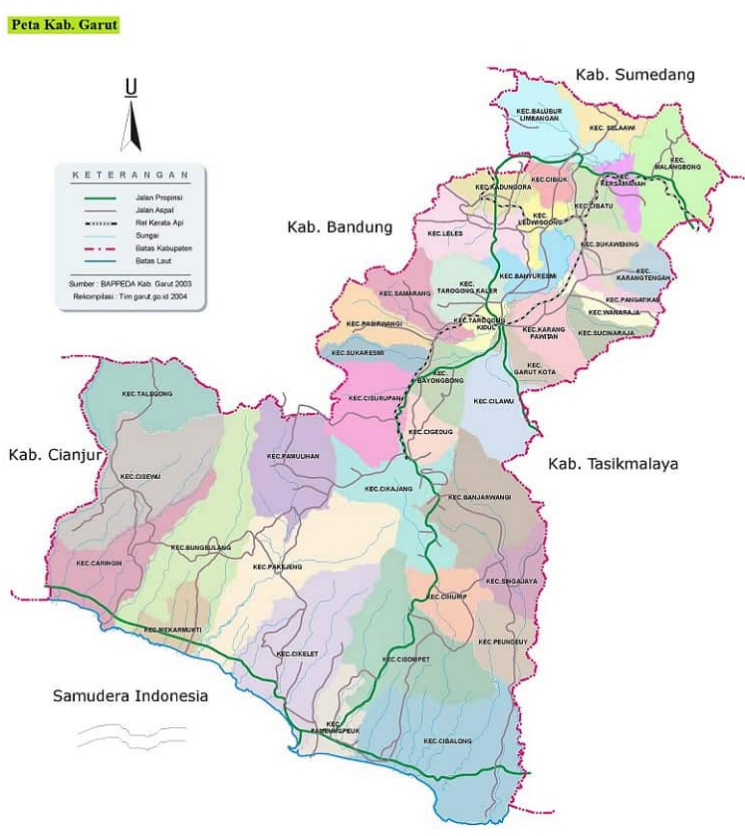

Gambar 1. Peta Kabupaten Garut (Sumber: http://peta-hd.com/peta-kabupatengarut/, 2021)

kuncen yang yang sudah wafat, atupun kuncen yang masih hidup, tidak hanya penduduk setempat tetapi masyarakat luarpun datang berkunjung meminta nasehat, dan petuah segala permasalahan. Ajaran-ajaran Kuncen pertama sampai saat ini masih dipatuhi dan dilaksanakan baik oleh penduduk maupun masyarakat yang datang dari luar daerah.

Kegiatan ziarah ke makom Syech Abd. Jalil juga kegiatan ritual agama masyarakat kampung Dukuh, dilaksanakan secara rutin mingguan, seperti pengajian Selasa, Jum'at untuk ibu-ibu yang dilaksanakan di Madrasah, dan untuk anak dan remaja setiap ba'dha shalat Ashar di masjid.

Ritual keagamaan mingguan ziarah makom ini dilaksanakan setiap Jum'at malam, yang dimulai setelah ba'dha shalat Isya sampai hari Sabtu. Ritual ini dipimpin langsung oleh pimpinan adat/Kuncen dibantu para Lawang. Kuncen dan Lawang sebagai pimpinan dalam kepengurusan adat Dukuh mempunyai tugas 
dan fungsi masing-masing. Seperti yang dikemukakan Imam Hilman (2017, hlm. 5) bahwa keberhasilan masyarakat Dukuh dalam mempertahankan tradisi budaya sebagai pranata sosial yang masih dapat tumbuh dan berkembang di tengah pengaruh zaman sekarang ini memberikan implikasi positif dalam kehidupan mereka.

Keterbukaan masyarakat luar datang berkunjung tentunya membawa budaya dan dampak yang berbeda, namun tidak merubah masyarakat Dukuh untuk tetap taat pada adat-istiadat yang telah berakar secara turun temurun, (wawancara Mama Uluk, 19 Maret 2021). Seperti juga yang dikemukakan Wibowo dalam (Syahrul Ibad, 2017, hlm. 27):

...fungsi dan makna kearifan lokal yaitu; berfungsi untuk konservasi dan pelestarian sumber daya alam, berfungsi untuk penegembangan sumber daya manusia, berfungsi untuk pengembangan kebudayaan dan ilmu pengetahuan, berfungsi sebagai petuah, kepercayaan, sastra dan pantangan, bermakna sosial ekonomi, bermakna etika dan moral, bermakna politik.

Wilayah Dukuh dalam kepemerintahan satuRukunWarga(RW), terdiridari masyarakat Dukuh Luar dan Dukuh Dalam yang disebut Masyarakat Adat. Perbedaan Luar dan Dalam terletak pada ketaatan terhadap aturan dan larangan yang dilaksanakan hal-hal tertentu, sesuai ajaran Syech Abdul Djalil, seperti yang dikatakan Nababan dalam Arnis Rochman Harani, dkk. (2017, hlm. 17):

Masyarakat Adat umumnya memiliki sistem pengetahuan dan pengelolaan lokal yang diwariskan dan ditumbuh kembangkan terus-menerus secara turun temurun. Pengertian masyarakat adat di sini adalah mereka yang secara tradisional tergantung dan memiliki ikatan sosial-kultural dan religius yang erat dengan lingkungan lokalnya.

Kedua masyarakat Dukuh Dalam dan Luar, masih terikat kekerabatan/pertalian darah, kharisma kuncen, dalam kehidupan sosial masyarakat saling bekerjasama. Hal ini terlihat pada saat membangun rumah, pernikahan, kematian, kegiatan keagamaan mingguan atau hari-hari besar dan lain-lain.

Wilayah kampung Dukuh yang dikelilingi oleh hutan dan sawah yang sangat berpotensi. Hutan yang dilindungi menjadi sumber air minum dan sumber pengairan pertanian, yang diolah masyarakat Dukuh untuk bersawah, berhuma, dan berkebun. Kebun/ tanah garapan selain ditanami pohon keras, juga ditanami tanaman yang dapat dipanen dalam waktu yang pendek seperti kacang tanah, pisang, serta ketela pohon dan lain-lain.

Potensi yang dimanfaatkan dari hasil pertanian baik dari kebun dan sawah awalnya hanya untuk memenuhi kebutuhan keluarga saja atau untukkeperluan upacara adat. Namun seiring dengan peningkatan kebutuhan dan perkembangan wisatawan, sekitar tahun 2000-an, masyarakat mulai mengolah sumber daya alam menjadi makanan untuk dijual, yang dijajakan langsung ke tamu, atau dijual pada saat acara ritual (wawancara, P. Ocid, 19 Maret 2021). Makanan tersebut dijual di tata Golodog/teras Bale adat, sebagai oleh-oleh.

Seperti yang dikemukakan Sophian Hidayat, Agus Hikmat, Ervizal AM Zuhud (2010, hlm. 149): 
Salah satu praktek konservasi masyarakat terlihat dari adanya pembagian lingkungan ke dalam lima bagian, yaitu hutan larangan, hutan tutupan, lahan garapan, lahan cadangan, lahan awisan/titipan. Pembagian seperti ini tentu memberikan manfaat kepada masyarakat untuk jelas pengelolaan wilayah agar tetap sejalan dengan aturan dan tidak ada tumpang tindih satu sama lain. Komponen sikap cognitive, affective, dan over action terpadu lengkap pada masyarakat untuk senantiasa menjaga dan memelihara lingkungan sehingga manfaatnya terasa sepanjang masa.

Pembagian dan pengaturan lahan sesuai aturan adat, merupakan salah satu keunikan ilmu pengetahuan yang dimiliki masyarakat Adat Dukuh yang disampaikan Syekh Abdul Jalil, untuk mengolah dan memanfaatkan secara benar tidak berlebihlebihan, memberikan gambaran bahwa keberlangsungan hidup masyarakat sudah jauh-jauh dipikirkan pimpinan untuk kesejahteraan warga/penduduknya.

Masyarakat Dukuh mempunyai prinsip hidup sederhana, sebagai petani masyarakatnya giat mengolah sumber daya alam, untuk memenuhi kebutuhan ekonomi dan meningkatkan kesejahteran hidup keluarga. Potensi-potensi yang dimilikinya menjadi sumber kreatif dan inovatif menjadi tambahan pendapatan keluarga dan ekonomi desa. Hal ini dapat dilihat dengan hasil pertanian yang dijual baik masih berupa mentahan atau sudah berbentuk olahan makanan khas sebagai oleh-oleh yang dapat dibeli para wisatawan yang berkunjung.

\section{METODE}

Penelitian ini menggunakan pendekatan kualitatif dengan metode deskriptif, adalah penelitian yang dilakukan pada kondisi alamiah, Sugiyono (2015, hlm. 14-15) , menjelaskan bahwa metode ini mengungkap kejadian atau fakta, keadaan, fenomena variabel dan keadaan yang terjadi saat penelitian berlangsung dengan menyuguhkan apa yang sebenarnya terjadi.

Adapun teknik pengumpulan data pada penelitian ini menggunakan tiga teknik, yaitu: 1) Observasi; 2) Wawancara; dan 3) dokumentasi.

Observasi merupakan teknik pengamatan dan pencatatan sistematis dari fenomena-fenomena yang diselidiki (Yaya Suryana dan Tedi Priatna, 2007, hlm. 188), Observasi dilakukan di Kampung Adat Dukuh untuk mengamati kegiatan wisata religi dan dampaknya bagi pemberdayaan ekonomi masyarakat.

Wawancara adalah proses percakapan dengan maksud untuk mengonstruksi mengenai orang, kejadian, kegiatan, organisasi, motivasi, perasaan, dan sebagainya yang dilakukan dua pihak pewawancara (interviewer) yang mengajukan pertanyaan dengan orang yang diwawancarai (interviewee) (Heru Irianto dan Burhan Bungin dalam Burhan Bungin, 2007, hlm. 155)

Wawancara dalam penelitian ini dilakukan kepada sejumlah pihak, yaitu tokoh adat, masyarakat, serta pengunjung wisata religi di Kampung Adat Dukuh.

Dokumentasi yaitu mencari data mengenai hal-hal atau variable yang berupa catatan, transkrip, buku, surat kabar, majalah, 
langkanya kendaraan umum yang hanya

prasasti, notulen rapat, lengger, agenda, dan sebagainya. (Suharsimi Arikunto, 2006, hlm. 231). Dokumentasi dilakukan untuk mendapatkan gambaran utuh berkaitan dengan data-data tentang aktivitas wisata religi serta data tentang pemberdayaan ekonomi masyarakat Kampung Adat Dukuh.

Tahapan selanjutnya data terkumpul, dilakukan analisis data untuk memilah dan menelaah keseluruhan data dan informasi yang berkaitan dengan aktivitas wisata religi dan pemberdayaan ekonomi masyarakat.

Tahapan akhir yaitu interpretasi data yang bertujuan untuk memadukan data dan informasi dengan teori-teori yang relevan dengan fokus penelitian.

\section{HASIL DAN PEMBAHASAN}

Secara geografis, Kampung Adat Dukuh terletak sekitar $120 \mathrm{~km}$ dari Pusat Kabupaten Garut, tepatnya di Desa Ciroyom Kecamatan Cikelet Kabupaten Garut. Kecamatan Cikelet Kabupaten Garut, memiliki banyak potensi wisata, seperti Pantai yang indah, Pantai Santolo, Pantai Heulang Garut, Pantai Cikaso, serta Pantai Gunung Geder. Selain wisata pantai, juga memiliki wisata lain yang tidak kalah menarik untuk dikunjungi, dengan keberadaan Kampung Adat Dukuh.

Kampung dengan luas 1.5 Ha ini dapat ditempuh dengan menggunakan kendaraan pribadi, yang tentunya secara kondisi bagus, lebih baik kendaraan yang biasa digunakan untuk kegiatan offroad. Perjalanan dari jalan raya utama Cikelet kurang lebih $7 \mathrm{Km}$, sarana jalan kondisinya berbatuan, menanjak dan sempit. Selain Kondisi tersebut masih ada satu hari satu kali itu juga kadang tidak menentu jadwalnya.

Kendaraan yang siap saat ini untuk mengantar para tamu yang tidak bawa kendaraan atau kendaraannya yang tidak memungkinkan untuk sampai ke tujuan, wisatawan dapat memanfaatkan layanan Ojeg pangkalan masyarakat setempat, dengan biaya satu kali jalan Rp.50.000/bisa lebih itu tergantung dari situasi dan kondisi alam.

Suasana Kampung Adat Dukuh dikeliling hutan, pesawahan dan perkebunan dan tidak terkontaminasi dengan penggunaan teknologi laiknya pada kampung-kampung lainnya. Masyarakat Kampung Adat Dukuh menganggap bahwa penggunaan teknologi modern dapat mempengaruhi tata hubungan manusia dengan alam. Seperti yang dikemukakan (Abdul Syukur dan Husnul Qodim,2016, hlm. 155):

Upaya menjaga suatu daerah untuk tetap lestari yang dilakukan oleh masyarakat akan dapat bertahan lama karena berangkat dari kesadaran masyarakat setempat menjaga kelestarian hutan berarti menjaga ekosistem yang didalamnya terdapat bermacam-macam tumbuh-tumbuhan dan hewan itu sebabnya di kampung Dukuh masih terdapat banyak jenis tanaman yang ditempat-tempat lainnya dianggap telah punah.

Masyarakat Dukuh merupakan masyarakat adat, lip Sarip Hidayana dan Rufus Goang Swaradesy (2021, hlm. 93) menjelaskan bahwa masyarakat adat merupakan salah satu kelompok masyarakat yang masih kuat menjaga sistem nilai tradisional dalam berbagai aspek kehidupan. Masyarakat 
Dukuh sangat menyatu dengan alam dan dikenal sebagai kampung yang sangat kental dengan nuansa religi. Hal ini dapat dilihat dari kehidupan sehari-hari mereka, yaitu dengan melakukan pengajian rutin, berziarah, serta kegiatan religi lainnya. Hal ini tidak hanya diikuti oleh masyarakat setempat saja, namun juga oleh pengunjung yang datang dari luar Kampung Adat Dukuh.

Wisatawan yang datang biasanya untuk bertemu dengan pimpinan adat "Kuncen", dan mereka juga tertarik mengetahui dan mempelajari aturan adat, seperti rumah tinggal, perabotan, pakaian, yang terangkum dalam Tilu Pacaduan, yaitu Pacaduan Kampung, Pacaduan Makom, Pacaduan Leuweung Larangan. Filsafat hidup yang menjadi ajaran turun temurun dari Eyang Abdul Jalil, "Apes lingsem" ajaran yang mempunyai pengertian yang luhur dan sangat dalam yaitu hidup sederhana". Filsafat hidup terus terjaga secara turun temurun, dengan kharisma dari setiap pimpinan adat melalui pikukuh pituturnya (Ai Juju Rohaeni dan Nia Emilda, 2020, hlm. 3536)

Masyarakat Kampung Dukuh sangat menjaga budaya tradisi yang sudah ada. Deni Yana, dkk. (2020: 208) menjelaskan bahwa budaya tradisi merupakan keseluruhan unsur kebudayaan yang sampai saat ini masih diteruskan dan diwariskan dari generasi sebelumnya.

Budaya tradisi yang terus diwariskan tersebut, membuat Kampung Dukuh banyak dikunjungi oleh wisatawan dengan berbagai kepentingan seperti pendidikan, penelitian, ataupun tujuan pribadi yang khusus, berdampak terhadap sosial budaya dan menjadi salah satu potensi peningkatan kesejahteraan masyarakatnya, seperti yang dikemukakan Oka A Yoeti (2008, hlm. 44) bahwa pariwisata dapat diandalkan untuk meningkatkan kesejahteraan masyarakat dan pengembangan nasional.

\section{A. Wisata Religi dan Ekonomi Kreatif Masyarakat}

Wisata Religi menurut Septia Arnisa Sari (2020, hlm. 14), "Wisata religi dimaknai sebagai kegiatan wisata ketempat yang memiliki makna khusus bagi umat beragama biasanya berupa tempat beribadah, makam ulama atau situs-situs kuno yang memiliki kelebihan".

Kunjungan masyarakat luar yang kadang datang dari luar Jawa Barat sebagai tamu/wisatawan ini mengikuti kegiatan ritual yang dimulai pada setiap hari Jum'at malam sampai hari sabtu. Kunjungan tersebut dengan berbagai tujuan dan kepentingan dari yang datang, seperti penelitian, mempunyai hajat, masalah pribadi/ keluarga, pendidikan dan lain-lain.

Pelaksanaan ritual Jum'at malam, dimulai setelah shalat Maghrib sampai menjelang pagi. Penyampaian Pikukuh Pitutur/nasehat agama yang diaplikasikan dengan kehidupan, dilanjutkan pembacaan Sholawat Nariyah sebanyak 4444 yang dibaca secara bersamasama dengan menggunakan alat bantu kerikil/ batu alam, selesai pengajian dilanjutkan Upacara Cebor 40, yang bermakna dan berfungsi sebagai ritual taubat/membersihkan penyakit Rohani dan Jasmani. Upacara ini tidak diikuti semua yang datang tetapi hanya diikuti pengunjung yang mempunyai tujuan/ 


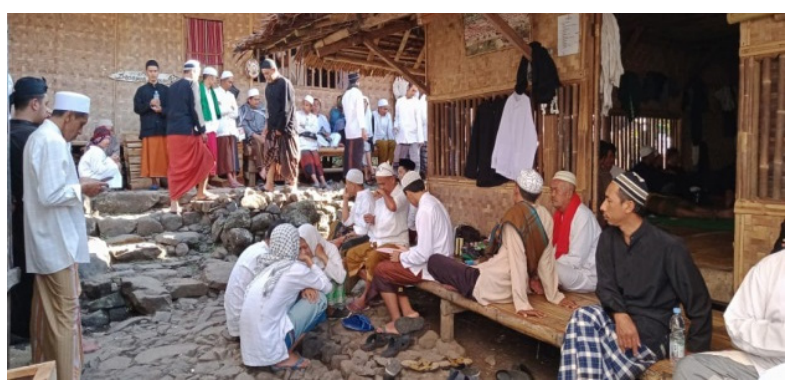

Gambar 2. Tamu dan penduduk pada kegaiatan ziarah setiap sabtu

(Sumber: Dokumentasi Ai Juju Rohaeni dan Nia Emilda, 2021)

hajat khusus, biasanya karena mempunyai masalah atau kesulitan hidup yang serius, dan besok harinya hari Sabtu dilanjutkan dengan kegiatan ziarah ke Makom Syeikh Abdul Jalil.

Kampung Dukuh memiliki Dukuh Dalam sebagai Masyarakat adat dengan kunjungan tamu yang memiliki berbagai maksud dan tujuan. Mereka datang tidak hanya pada saat acara ritual agama rutin mingguan atau hari-hari besar saja, dan hal ini memberi dampak positif bagi pendapatan masyarakat Dukuh Dalam dan Luar untuk mempunyai kreativitas memanfaatkan sumber daya alam dan sumber daya manusia.

\section{B. Potensi Sumber Ekonomi Kreatif Masyarakat}

Masyarakat Dukuh merupakan masyarakat petani, awalnya hanya mengolah dan memanfaatkan sumber daya alam untuk kehidupannya. Seiring berjalannya waktu dan banyaknya tamu yang datang, potensi-potensi yang ada baik itu dari sumber daya alam, adat istiadat setempat, rumah penduduk untuk menginap, menjadi sumber kreatif masyarakat yang bernilai dengan tetap menjaga dan melestarikan kearifan lokal budayanya. Seperti yang dikatakan (Siti Nur azizah dan Muhfiatun, 2017, hlm. 68):
Mengembangkan ekonomi kreatif berbasis budaya dan kearifan lokal adalah solusi alternatif untuk menstimulus perkembangan ekonomi kreatif untuk bisa mandiri dan bisa mengembangkan usaha terutama di daerah. Pada umumnya setiap daerah memiliki potensi produk yang bisa diangkat dan dikembangkan keunikan atau kekhasan produk lokal itulah yang harus menjadi inti, kemudian ditambah unsur kreatifitas dengan sentuhan teknologi.

Sepertijuga yang dikemukakan Howkins dalam Heri Saksono (2012, hlm. 95) “Ekonomi kreatif merupakan aktivitas perekonomian yang lebih mengandalkan ide atau gagasan (kreatif) untuk mengelola material yang bersumber dari lingkungan sekitarnya menjadi bernilai tambah ekonomi". Perkembangan kehidupan dan kebutuhan manusia, sejalan dengan perkembangan jaman.

Masyarakat Dukuh yang mempunyai filsafat hidup sederhana, bukan berarti tidak membutuhkan peningkatan kesejahteraan seperti peruntukan keberlangsungan pertanian, pendidikan anak-anak, ada diantara yang di pesantrenkan ke luar Jawa Barat, juga ada yang melanjutkan pendidikan umum sampai menjadi sarjana kesehatan dan lain-lain.

\section{Pemanfaatan Rumah Penduduk}

Ketaatan terhadap ajaran Syekh Abdul jalil, yang terkenal dengan Tilu Pacaduan, yaitu Pacaduan kampung, Pacaduan Makom dan Pacaduan Leuwueng larangan tersebut. Keberlangsungan ziarah makom yang menjadi salah satu daya tarik wisata religi yang banyak dikunjungi wisatawan dari luar wilayah.

Tamu/wisatawan yang datang dengan 


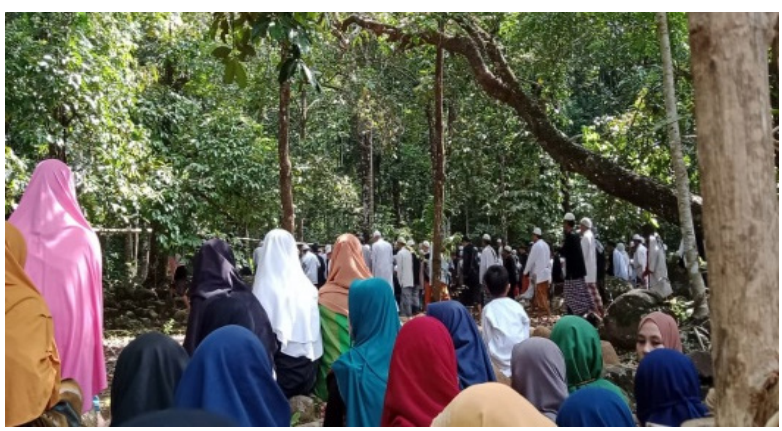

Gambar 3. Kegiatan pengunjung ziarah setelah pengajian jumat malam

(Sumber: Dokumentasi Ai Juju Rohaeni dan Nia Emilda, 2021)

lokasi yang susah dijangkau sehingga mereka menginap, apalagi bagi tamu yang mempunyai maksud/hajat khusus, tentunya berdampak pada penyediaan sarana dan prasarana penduduk untuk menyediakan kebutuhan selama berada di sana. Hal ini menjadi tambahan pendapatan penduduk walaupun belum ada tarif khusus untuk biaya menginap dan lain-lainnya.

Kunjungan tamu/wisatawan dengan berbagai kepentingan, yang datang di luar wilayah, rata-rata menginap minimal satu malam untuk mengikuti ritual Jum'at malam, tetapi juga ada yang menginap sesuai dengan hajatnya, tujuh malam sampai 40 malam sampai maksudnya terjawab atau ada jalan keluarnya, Tentunya para tamu memerlukan fasilitas serta berbagai kebutuhan, seperti untuk menginap dan keperluan lain sehari-hari selama di Dukuh. Menurut Aartje Tehupeiory (2019, hlm. 46) "...potensi keindahan alam desa, dapat dikemas secara kreatif dan inovatif dengan membuat konsep desa wisata, di mana rumah-rumah masyarakat desa dapat dijadikan homestay untuk para wisatawan menginap".

Rumah-rumah penduduk Dukuh Dalam maupun Luar, terbuka untuk menjadi tempat menginap dan menyediakan kebutuhan tamu, tanpa mengubah apapun sehingga menjadi salah satu daya tarik, selain itu juga masyarakatnya terbuka memberi informasi yang dibutuhkan dengan adabadab yang mengikat untuk informasi tertentu yang hanya boleh disampaikan oleh Kuncen atau Lawang serta tokoh yang sudah diberi wewenang untuk menyampaikan.

Rumah penduduk Dukuh sebagai homestay para wisatawan, sampai saat ini belum ada standar khusus tarif,diperlukan kepekaan dan kesadaran para tamu untuk memberi imbalan dan rasa terima kasih atas bantuan dan pelayanan, hal ini menjadi pendapatan tambahan bagi ekonomi keluarga.

2. Pemanfaatan Sumber Daya Alam

Potensi alam yang subur mendukung masyarakat Dukuh sebagai petani untuk memanfaatkan dan mengolah menjadi berbagai makanan. Olahan tersebut yang awalnya hanya untuk memenuhi kebutuhan keluarga dan momen-momen tertentu saja, sepertihajatan/syukuran dan upacara-upacara keagamaan. Seiring dengan kemajuan jaman akan kebutuhan hidup, olahan hasil dari sawah, kebun, kolam, selain untuk kebutuhan keluarga mulai tahun 2000-an mulai dijual untuk oleh-oleh, dengan kemasan sampai saat ini masih sederhana sekali.

Pemasaran khas makanan yang awalnya hanya dijajakan di golodog/teras bale adat dan rumah penduduk Dukuh Dalam, Tahun 2018 mulai berdiri satu warung oleh-oleh yang didirikan di wilayah Dukuh Luar. Penempatan warung oleh-oleh strategis berada di area jalan yang dilalui kedatangan dan kepulangan wisatawan yang ke Dukuh Dalam atau luar, 


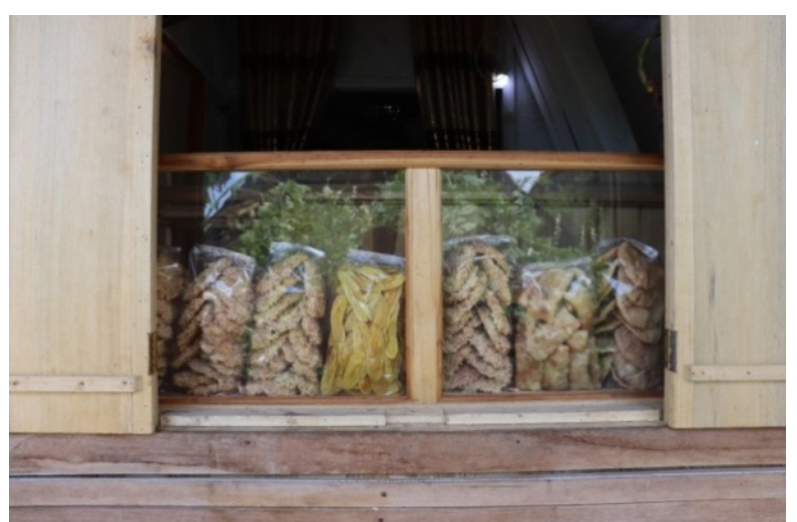

Gambar 4. Warung yang menjual oleh-oleh berlokasi di Dukuh Luar

(Sumber: Dokumentasi Ai Juju Rohaeni dan Nia Emilda, 2021)

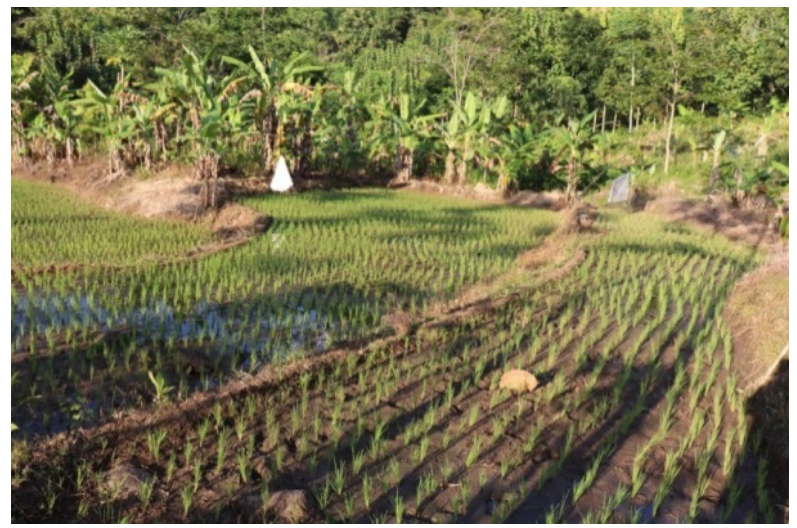

Gambar 5. Pesawahan dan perkebunan Dukuh (Sumber: Dokumentasi Ai Juju Rohaeni dan Nia Emilda, 2021)

juga berada di lokasi terbuka tempat parkir kendaraan roda dua dan para wisatawan bisa berisitirahat sejenak.

Warung tidak boleh didirikan di Dukuh Dalam karena melanggar salah satu larangan/ pamali. Bagi masyarakat adat tidak boleh mendirikan bangunan permanen untuk dijadikan warung, karena akan mempengaruhi pada tatanan kehidupan, yang dikhawatirkan mempengaruhi persaingan secara duniawi, sehingga masyarakat Dukuh Dalam membuat makanan khas bisa dijual di warung yang berlokasi di Dukuh luar.

Kebun dan sawah yang luas dan subur, tidak hanya ditanami pohon-pohon keras yang memakan waktu bertahun-tahun untuk

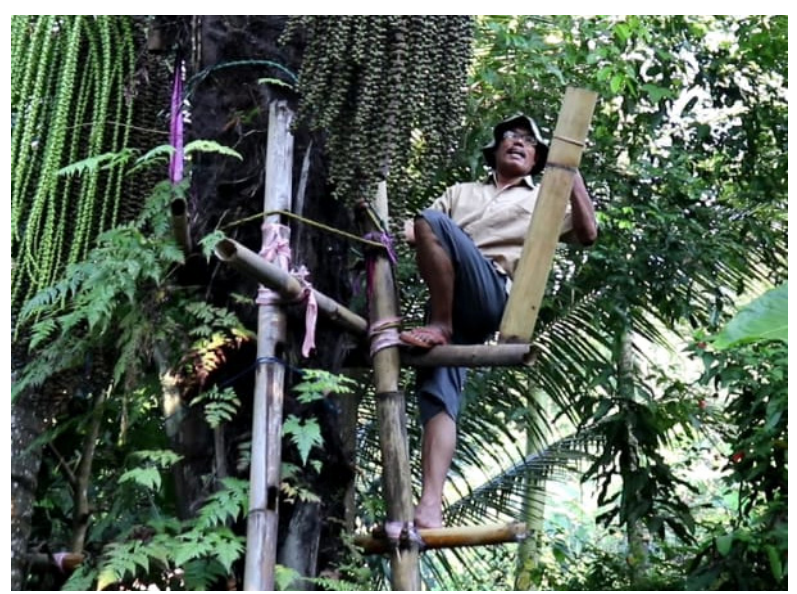

Gambar 6. Proses pengambilan bahan untuk gula aren/merah

(Sumber: Dokumentasi Ai Juju Rohaeni dan Nia Emilda, 2021)

dimanfaatkan/ dijual, tetapi juga ada tanamantanaman tertentu sebagai tanaman sela, yang dalam waktu pendek 3-4 bulan dapat menjadi olahan yang mempunyai nilai jual, sebagai oleh-oleh para tamu yang berkunjung, juga tanaman yang dapat dijadikan obat-obatan.

a. Pohon Aren

Pohon Aren banyak tumbuh di kebun yang dimiliki masyarakat Dukuh dan menjadi salah satu sumber penghasilan tambahan masyarakat. Hasil dari pohon Aren tersebut, oleh masyarakat dijadikan Gula merah, kolang kaling. lahang (bahan untuk diolah menjadi gula) banyak juga yang membutuhkan bisa dijual, selain rasanya yang khas juga dipercaya sebagai obat, ijuknya selain digunakan untuk atap rumah, juga bisa dijual.

Para wisatawan dapat ikut dalam pembuatan Gula Aren. Pengolahan dengan sarana dan cara atau teknik pembuatan masih tradisional, menjadi daya tarik tersendiri, terutama bagi para tamu yang datang dari kota yang belum pernah mengetahui. Satu toros kemasan dengan daun kelapa kering dijual seharga Rp. 21.000;. 

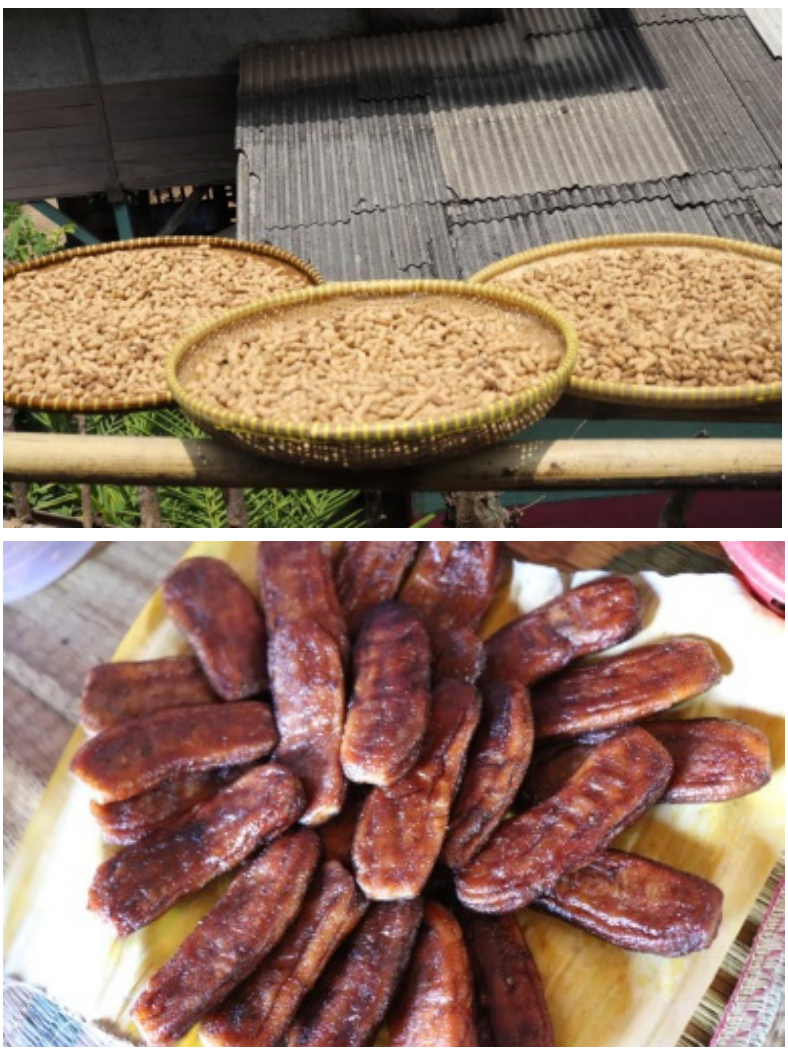

Gambar 7. Olahan oleh-oleh Kampung Dukuh (Sumber: Dokumentasi Ai Juju Rohaeni dan Nia Emilda, 2021)

\section{b. Pisang dan Kacang Tanah}

Pisang salah satu tanaman yang banyak dan mudah ditanam di kebun dan pematang/ galeng pesawahan, selain diolah untuk makanan keluarga saja pada awalnya, seiring berkembang kebutuhan menjadi olahan oleholeh seperti dibuat keripik dan sale pisang, dengan kemasan plastik sederhana tanpa merk dagang dijual perbungkus Rp. 10.000;.

Kacang tanah sebagai tanaman penyela yang ditanam di kebun, dengan rasanya khas dengan kreatifitas diolah disangrai tanpa minyak, oleh ibu-ibunya, menjadi makanan ringan/cemilan, dikemas sederhana dijual perbungkus Rp.10.000;

c. Madu Dukuh

Madu mempunyai khasiat untuk obat secara alami, baik diminum atau disatukan dengan makanan dan minuman.

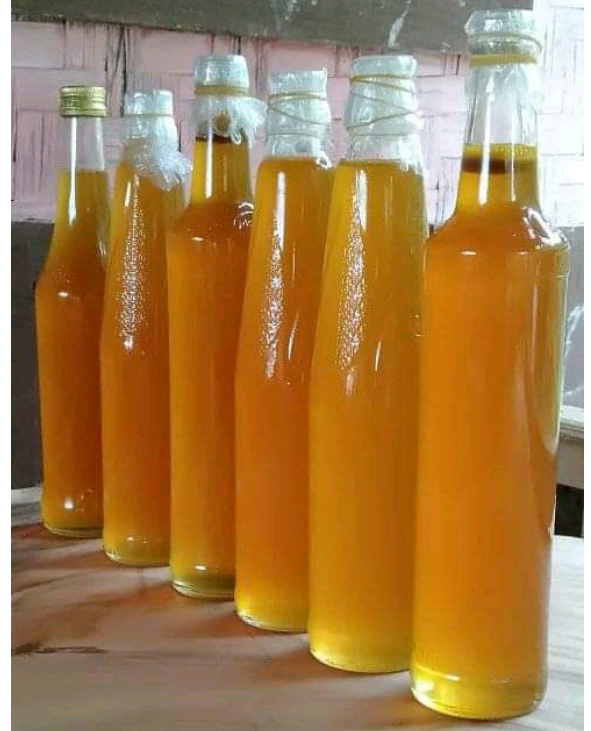

Gambar 8. Madu Dukuh salah satu potensi pendapatan masyarakat

(Sumber: Dokumentasi Ai Juju Rohaeni dan Nia Emilda, 2021)

Peternakan Lebah merupakan salah satu yang dikembangkan oleh masyarakat Dukuh. Kemasan dan tampilan Madu masih sederhana, dengan memanfaatkan botol kecil dan besar, tanpa campuran menjadi ketertarikan para tamu untuk membeli.

Madu dapat ditemukan para tamu karena dijajakan di depan teras rumah Dukuh Luar, dan jajakan di teras Bale adat Dukuh Dalam pada saat acara ziarah tamu banyak datang. Kemasan dalam bentuk botol ukuran kecil dan ukuran besar/botol kemasan sirop. Botol kecil dijual Rp.25.000;, dan ukuran besar/ botol bekas sirop dijual Rp.100.000.

d. Olahan Bahan Beras Ketan

Olahan dari bahan beras ketan yang diproduksi ibu-ibu baik Dukuh dalam dan Luar, yaitu Opak. Opak awalnya dibuat sekedar untuk cemilan keluarga, atau untuk suguhan pada acara syukuran dan acara ritual adat, dengan berjalannya waktu dan kebutuhan ekonomi masyarakat saat ini diproduksi untuk dijadikan oleh-oleh. Opak yang dibuat 


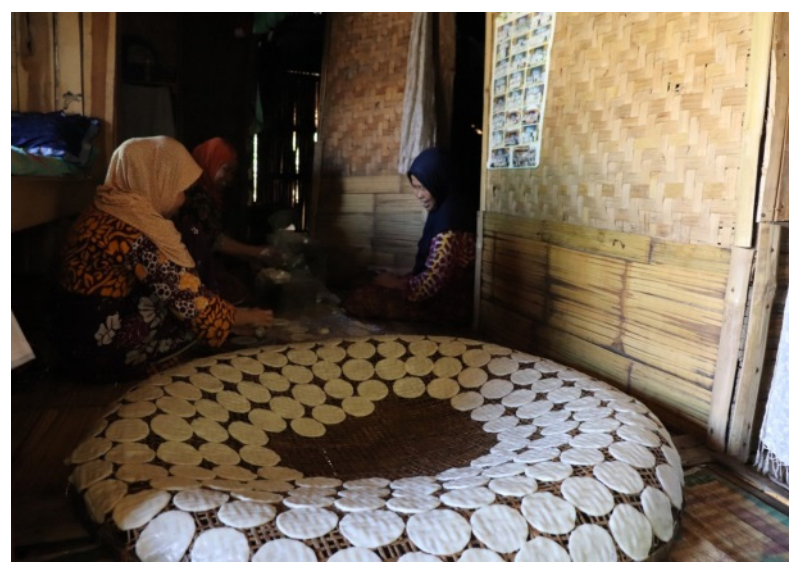

Gambar 9. Proses pengerjaan pembuatan opak (Sumber: Dokumentasi Ai Juju Rohaeni dan Nia Emilda, 2021)

setiap Masyarakat Sunda mempunyai rasa, yang khas, seperti juga Opak Dukuh.

Pengolahan dan pembuatan Opak yang unik diperlukan ketekunan, ketelatenan, kesabaran dan rasa seni, kenapa demikian dengan pembuatan secara manual bentukdan ukuran dari olahan opak kelihatan sama, dapat dilihat pada saat penjemuran yang menggunakan ayakan besar dari bahan bambu, dan pada saat ditata di plastic untuk dijual.

Opak Dukuh masih dalam kemasan seadanya, satu bungkus plastik dijual Rp.10.000;. Pengolahan dan pembuatan makanan Opak ini sangat menarik untuk dicoba, namun tidak serta merta langsung bisa dan jadi seperti yang dibuat oleh IbuIbu masyarakat Kampung Dukuh, dengan keterampilan tangan dalam pembuatan, kepekaan estetik,perasaan, dan kemampuan visual sangat dibutuhkan.

e. Pakaian Pangsi Hitam

Pakaian Pangsi/koko berwarna polos baik itu hitam/putih merupakan salah satu aturan yang harus ditaati baik oleh penduduk maupun tamu yang akan ikut pada kegiatan ritual agama, juga dalam kehidupan harian

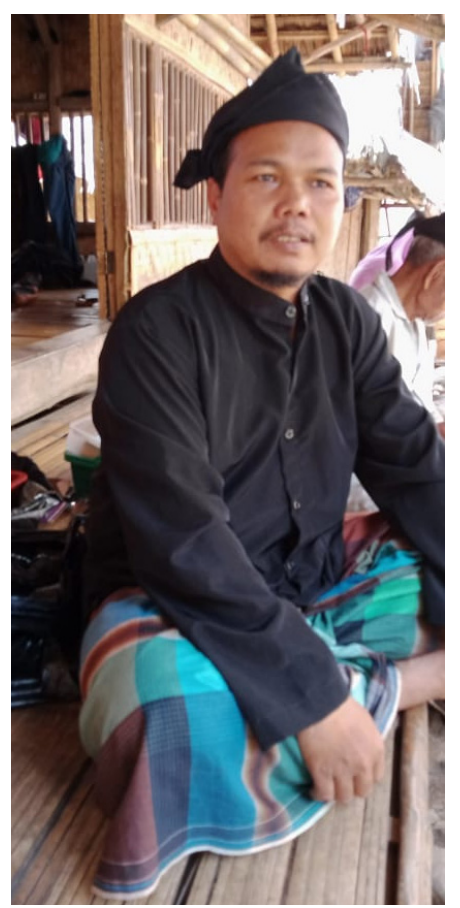

Gambar 10. Ust. Nasrulloh, salah satu tokoh dengan pakaian adat

(Sumber: Dokumentasi Ai Juju Rohaeni dan Nia Emilda, 2021)

terutama pada saat ritual agama dan upacaraupacara adat. Warna polos berkaitan dengan filsafat hidup yang dianut dan dilaksanakan Masyarakat Adat Dukuh dalam, diantaranya kesederhaan, tidak hidup bermewahmewahan yang dikhawatirkan akan menjadi konflik.

Pemakaian pangsi dilengkapi dengan ikat kepala/Totopong. Pemakaian ikat kepala merupakan salah satu warisan budaya leluhur masyarakat Sunda bukan sekedar gaya atau penampilan belaka. Ikat kepala ini memiliki makna dan filosofi yang dalam serta banyak macam ragam dalam bentuk pemakaiannya. Baju pangsi hitam, salah satu yang dijajakan di saat banyak wistawan datang pada acara ziarah ke makom Syekh Abdul Jalil. Produk pakaian adat ini belum merupakan produksi masyarakat Dukuh. Baju atasan pangsi hitam dengan berbahan katun dijual seharga Rp.80.000/potong. 


\section{SIMPULAN}

Kehidupan masyarakat Dukuh terutama Dukuh Dalam yang kental dengan tradisi taat pada ajaran dari Syeikh Abdul jalil yang secara terus menerus diwariskan dari generasi ke generasi, berdampak pada kehidupan Masyarakat Dukuh untuk mempunyai kreatifitas menambah pendapat ekonomi keluarga.

Keterbukaan masyarakat Adat Dukuh Dalam terhadap masyarakat luar, tidak mempengaruhi pada keberlangsungan ketaatan pada adat istiadat Tilu Pacaduan yang terus meneruskan diwariskan dari generasi terdahulu ke generasi berikutnya. Kebedaradaan sosok seorang Kuncen, sebagai pemimpin adat yang kharismatik selalu ditaati dan menjadi panutan. Potensi alam menjadikan sumber yang tertata pengaturannya untuk keberlangsungan kehidupan masyarakat Dukuh, menjadikan bahan yang dapat terus digali untuk meningkatkan perekonomian tidak hanya perekonomian keluarga tetapi dapat menjadi tambahan perekonomian daerah.

Keberlangsungan ekonomi kreatif dengan produk berbasis budaya lokal perlu untuk terus dikembangkan. Diperlukan adanya perhatian, dukungan dan kerjasama pemerintah, perguruan tinggi dan UKM. Pengembangan bentuk, jenis dan kemasan produk, yang mempunyai kekhasan dan keunikan bercirikan budaya lokal, dapat menjadi nilai jual lebih dan dapat dipasarkan ke luar tidak hanya di sekitar Kampung Dukuh saja.

\section{DAFTAR PUSTAKA}

Arikunto, Suharsimi. (2006). Prosedur Penelitian: Suatu Pendekatan Praktik. Jakarta: Rineka Cipta.

Azizah M, Siti Nur Dkk. (2017) Pengembangan Ekonomi Kreatif Berbasis Kearifan Lokal Pandanus Handicraft Dalam Menghadapi Pasar Modern. APLIKASI ILMU-ILMU AGAMA, Vol.17 No.2.

Bungin, Burhan. (2007). Metode Penelitian Kualitatif: Aktualisasi Metodologis ke Arah Ragam Varian Kontemporer. Jakarta: RajaGrafindo Persada.

Harani, Arnis Rochman dkk. (2017). Pemetaan Potensi Desa Menuju Desa Wisata Yang Berkarakter". MODUL Vol.17 No.1 JanJun.

Hidayana, Iip Sarip. (2021). Pemaknaan Permainan Rakyat pada Ritual Kematian Rambu Solo' di Kampung Adat Ke'Te'Kesu' Kabupaten Toraja Utara Provinsi Sulawesi Selatan. PANGGUNG, V31/N2/06/2021.

Hidayat, Sopian Dkk. (2010). Kajian Etnobotani masyarakat kampung Dukuh kabupaten garut Jawa Barat. Media Konservasi, Vol.15 No.3 Desember.

Ibad, Syahrul. (2017). Kearifan Lokal Pemberdayaan Masyarakat Dalam Pengelolaan Dan Pembangunan Sumber Daya Perikanan yang Berkelanjutan. Samakia. Vol.8 No.1 April.

Iman, Hilman. (2017). Kearifan Lokal Masyarakat Adat Kampung Dukuh Sebagai Cagar Budaya di Desa Ciroyom Kecamatan Cikelet kabupaten garut Propinsi Jawa Barat. Tasikmalaya, UNSIL.

Rohaeni, Ai Juju R Dkk. (2020). Pikukuh Pitutur Apes Lingsem Bagi Masyarakat Kampung Adat Dukuh Kabupaten Garut. ATRAT, Vol 8 No.3 Sept.

Saksono, Heri. (2012). Ekonomi Kreatif Talenta Baru Pemicu Daya Saing Daerah. BINA PRAJA, Vol,4 No.2.

Sari, Septia Arnisa. (2020).Pengaruh Kunjungan Wisata Religi Makam Syekh Abdurahman Siddik Terhadap Pendapatan Pedagang Muslim Sekitar Objek Wisata Desa Hidayat Kec.Sungai Indragiri Kab. Indragiri Hilir, Riau. Jambi: UIN Sultan 
Thaha Sarifuddin.

Sugiyono. (2015). Metode Penelitian Pendidikan Kualitatif/Kuantitatif. Bandung: Defabeta.

Suryana, Yaya dan Tedi Priatna. (2007). Metode Penelitian Pendidikan. Bandung: Azkia Pustaka Utama.

Syukur, Abdul Dkk. (2016).Islam,Tradisi Lokal,Konservasi Alam. Kalam, Vol.10, No.1, Juni.

Tehupeiory, Aartje. (2019). Pemberdayaan Masyarakat Hukum Adat (Masyarakat Desa) Dalam Mendukung Program Ekonomi Kreatif Desa Sesuai UndangUndang Desa. To'-ra', Vol. 5, No.2 Agustus.

Yana, Deni., dkk. (2020). Budaya Tradisi sebagai Identitas dan Basis Pengembangan Keramik Sitiwinangun di Kabupaten Cirebon. PANGGUNG, V30/N2/06/2020.

Yoeti, Oka A. (2008). Ekonomi Parawisata: Introduksi Informas dan Implementasi. Jakarta: Kompas.

\section{Daftar Nara Sumber:}

Mama Uluk (Maret 2021) Kuncen Dukuh ke 14.

P. Abdul jalil (Maret 2021), Keturunan dan Keluarga Kuncen berada di Dukuh Luar.

P. H. Agus (Maret 2021) salah satu tokoh Penduduk Dukuh Dalam, mempunyai

warung di luar dan memproduksi makanan oleh-oleh Dukuh.

P. Iip (Maret 2021) Pemuda dan Keturunan Kuncen Dukuh Dalam.

Ma Jijoh (Maret 2021) Penduduk Dukuh luar, salah satu pengolah Gula Aren dan rumahnya sebagai Homestay.

Ma Komsiah (Maret 2021) Seorang Lawang perempuan Dukuh Dalam.

P. Ocid (Maret2021) Tokoh, Pemuda dan Ketua RT. 